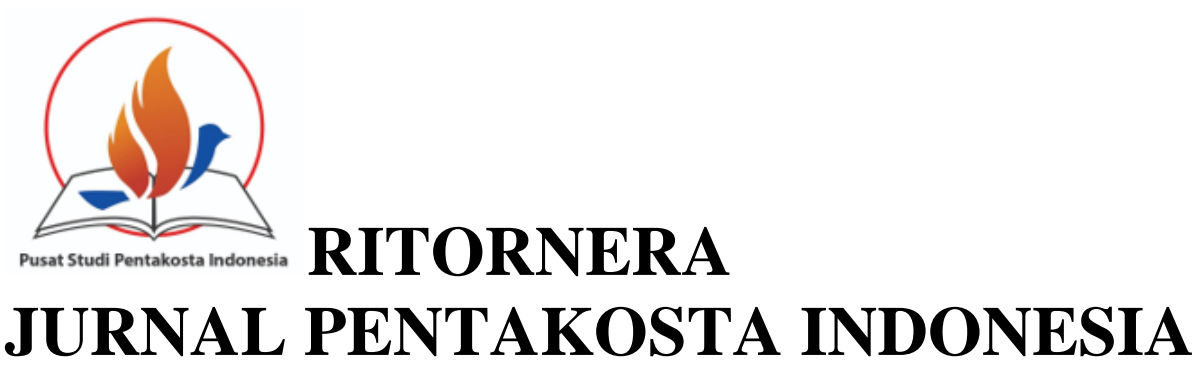

Vol. 1, No. 3, Desember 2021

Available at: pspindonesia.org

\title{
H.L. Senduk dan Kegerakan Pentakosta di Indonesia
}

\author{
Heppy Yohanes ${ }^{1}$ \\ heppyyohaneslim@gmail.com \\ Yakub Hendrawan Perangin Angin ${ }^{2}$ \\ yakub.hendrawan@sttbetheltheway.ac.id \\ Tri Astuti Yenirenowati ${ }^{3}$ \\ triastuti@sttekumene.ac.id
}

\begin{abstract}
H.L. Senduk is a well-known spiritual figure in Indonesia, especially among Pentecostals. Since his conversion and experience of the baptism of the Holy Spirit, he has followed in the footsteps of his teacher Rev. Van Gessel at the Pentecostal Church, until finally he founded the Full Gospel Bethel Church (GBIS). Over time he experienced conflicts and eventually left and founded the Indonesian Bethel Church (GBI). The life and ministry of H.L. Senduk is very influential for Pentecostals in Indonesia as seen from the GBI synod, which is the third largest synod in Indonesia in 2021 and continues to experience growth both in quantity and quality. H.L. Service This amazingly impactful spoon is definitely something that many Christians should know and very important to learn. Writing the story of H.L. This Senduk uses a qualitative method with a narrative approach in order to get a clear picture of the life of H.L. Senduk from various sources, so that we can know the spiritual heritage that is very important for the church in Indonesia. The spiritual legacy of H.L. Senduk will certainly have to do with his theological views, his leadership, and his ministry. H.L.'s theological view the main thread for the Pentecostal churches is related to the importance of the church to be open and dynamic to the guidance and work of the Holy Spirit. H.L. Leadership Senduk is certainly very important to follow, because it has an impact by making the GBI sindoe as big as it is now. Visionary leadership by setting an example and displaying good character for all circles. H.L. Service Senduk which emphasizes evangelism encourages GBI to continue to serve with realistically- socially in a relevant and effective manner.
\end{abstract}

Keywords: H.L. Senduk, Om Ho, Prof. Dr. Ho Lukas Senduk, Ho Liong Seng, Pentecostal Church, Pentacostal Movement, Gereja Bethel Injil Sepenuh, GBIS, GPdI, Gereja Bethel Indonesia, GBI

\begin{abstract}
Abstrak
H.L. Senduk merupakan salah seorang tokoh rohani yang dikenal di Indonesia, khususnya bagi kalangan Pentakosta. Sejak pertobatannya dan pengalaman akan baptisan Roh Kudus, ia mengikuti jejak gurunya Pdt. Van Gessel di Gereja Pentakosta, hingga akhirnya ia mendirikan Gereja Bethel Injil Sepenuhnya (GBIS). Seiring berjalannya waktu ia mengalami konflik dan akhirnya keluar dan mendirikan Gereja Bethel Indonesia (GBI). Kehidupan dan pelayanan H.L. Senduk sangatlah berpengaruh bagi kalangan Pentakosta di Indonesia yang terlihat dari sinode GBI merupakan sinode terbesar ketiga di Indonesia pada tahun 2021 dan terus mengalami pertumbuhan baik secara kuantitas ataupun kualitas. Pelayanan H.L. Senduk yang berdampak luar biasa ini pastinya merupakan sesuatu hal yang harus diketahui oleh banyak orang Kristen dan sangat penting untuk dipelajari. Penulisan kisah H.L. Senduk ini menggunakan metode kualitatif dengan pendekatan Naratif dengan studi kepustakaan agar mendapatkan gambaran yang jelas mengenai kehidupan H.L. Senduk dari
\end{abstract}

Copyright(C) 2021; Ritornera - Jurnal Teologi Pentakosta Indonesia ISSN 2797-7676 (online), 2797$717 \mathrm{x}$ (print) $\mid 101$ 
berbagai sumber, sehingga bisa mengetahui warisan rohani yang sangat penting bagi gereja di Indonesia. Warisan rohani H.L. Senduk pastinya akan terkait dengan pandangan teologisnya, kepemimpinan yang ia lakukan, dan pelayanannya. Pandangan teologis H.L. Senduk yang paling utama bagi gereja-gereja pentakosta adalah terkait dengan pentingnya gereja untuk terbuka dan dinamis terhadap tuntunan dan karya Roh Kudus. Kepemimpinan H.L. Senduk pastinya sangat penting untuk diteladain, karena berdampak dengan membuat sindoe GBI sebesar sekarang. Kepemimpinan yang visioner dengan memberikan teladan dan menampilkan karakter yang baik bagi seluruh kalangan. Pelayanan H.L. Senduk yang menekankan penginjilan mendorong GBI untuk terus melayani secara realistis sosial dengan relevan dan efektif.

Kata kunci H.L. Senduk, Om Ho, Prof. Dr. Ho Lukas Senduk, Ho Liong Seng, Gereja Pentakosta, Kegerakan Pentakosta, Gereja Bethel Injil Sepenuh, GBIS, GPdI, Gereja Bethel Indonesia, GBI

${ }^{1}$ Pusat Studi Pentakosta Indonesia

${ }^{2}$ Sekolah Tinggi Teologi Bethel The Way

${ }^{3}$ Sekolah Tinggi Teologi Ekumene

\section{PENDAHULUAN}

Ho Liong Seng adalah nama asli dari H.L. Senduk yang lahir di Ternate tanggal 4 Agustus 1917. ${ }^{1}$ Ho Liong Seng lebih dikenal dengan nama Pendeta Prof. Dr. Ho Lukas Senduk yang biasa disebut dengan pendeta H.L. Senduk, bahkan ada juga yang memanggilnya dengan sebutan om Ho. Pada saat H.L. Senduk berumur 16 tahun, ia bekerja di Ambon pada perusahaan minyak dan memulai perjalanan rohaninya dari pertobatan (lahir baru), baptisan air, dan baptisan Roh Kudus. ${ }^{2}$ Sejak permulaan perjalanannya sangatlah kental dengan nuansa pentakosta, karena om Ho mengalami baptisan Roh Kudus. Sejak bertobat pun om Ho bergereja di gereja Pantekosta (De Pinkster Gemeente in Nederlandsche Indie) dan pada tahun 1936 ia mulai belajar di sekolah Alkitab etherlands Indies Bible Institute (NIBI) dengan gurunya Pdt. Frans Gerald van Gessel, bahkan dalam perjalanan hidupnya selain melayani Tuhan ia juga berbisnis. ${ }^{3}$ H.L. Senduk yang merupakan seorang pelaku bisnis dan juga pelayan Tuhan pastinya dikenal pada kalangan Kristen di Indonesia. Ia memiliki kehidupan yang berpengaruh bagi gereja di Indonesia, khususnya untuk sinode Gereja Pantekosta di Indonesia (GPdI), sinode Gereja Bethel Injil Sepenuh (GBIS), Gereja Bethel Indonesia (GBI), dan kalangan Pentakosta.

Penelitian studi tokoh ini diangkat dari sudut aksiologis yaitu dari sisi kegunaannya, sikap teladanan, sebagai acuan refleksi diri bagi para tokoh masa kini dan masa depan, dan

1 “Ho Lukas Senduk," https://dbr.gbi-bogor.org/wiki/Ho_Lukas_Senduk.

${ }^{2}$ Ibid.

${ }^{3}$ Ibid. 
memberi sumbangan bagi perkembangan masyarakat dan ilmu pengetahuan. ${ }^{4}$ Ditinjaun dari sudut pengaruhnya bagi masyarakat, maka studi tokoh sangat memiliki relevansi dan sumbangsih yang sangat signifikan guna kesejahteraan umat dan kehidupan masyarakat. ${ }^{5}$ Maka penelitian ini diarahkan pada bagaimana Sumbahsih perjalanan yang dilakoni oleh H.L. Senduk. Sumbangsih yang dapat dipetik dari H.L. Senduk dapat dikatakan sebagai warisan rohani yang sangat penting bagi gereja, karena terdiri dari pemikirannya akan teologi pentakosta, kepemimpinan, nilai-nilai, dan dampak kehidupannya.

\section{METODE}

Metodologi kualitatif dengan pendekatan Naratif adalah merupakan penelitian kualitatif berupa studi untuk mendapatkan data mengenai perjalanan kehidupan seseorang / sejarahnya yang dibuat menjadi laporan secara narasi dan memiliki kronologi. ${ }^{6}$ karena peneliti membuat hubungan yang sangat dekat dengan partisipan yang dituangkan dalam bentuk bentuk literasi yang persuasive berfokus pada cerita individu ${ }^{7}$ Pendekatan Naratif yang dalam penuturannya dapat terdiri dari beberapa jenis, yaitu: Biografi, Autobiografi, Life History, dan Oral History. ${ }^{8}$ Pendekatan riset Biografi merupakan penelitian yang mengutamakan pembahasan tentang sejarah dari proses kehidupan seseorang yang dikemukan dalam bentuk tulisan oleh peneliti lain. ${ }^{9}$ Salah satu prosedur dalam penelitian pendekatan Naratif dengan jenis Biografi menurut Smith yang dikutip oleh Andreas Subagyo dilakukan dengan tahapan pertama adalah memilih seorang tokoh penting dan berusaha menemukan sumber data, membangun atau memakai arsip, menemukan dan mengembangkan satu tema yang akan dipakai untuk menggabungkan kehidupan, memahami sifat yang sebenarnya, memutuskan bentuk atau jenis biografi yang akan ditulis serta menentukan konteks kehidupan tokoh yang akan dipakai sebagai konteks penulisan ${ }^{10}$. Untuk mendukung proses penarasian ini, pastinya dilakukan studi kepustakaan yang dilakukan dengan menggunakan buku-buku sebagai sumber. ${ }^{11}$ Studi kepustaan dilakukan

\footnotetext{
${ }^{4}$ Syahrin Harahap, Metodologi Studi Tokoh Dan Penulisan Biografi, 2nd ed. (Jakarta: Prenada Media, 2014), 7.

${ }^{5}$ Arief Furchan and Agus Maimun, Studi Tokoh Metode Penelitian Mengenai Tokoh, 1st ed. (Yogyakarta: Pustaka Pelajar, 2005).

${ }^{6}$ Sugiyono, Metode Penelitian Manajemen, 3rd Ed. (Bandung: Alfabeta, 2014).

${ }^{7}$ H. Imam Ghozali, Metodologi Penelitian Kualitatif Analisis Data Kualitatif Dengan NVIVO 12, 1st ed. (Semarang: Yoga Pratama, 2020).

${ }^{8}$ Hamzah Amir, Metode Penelitian Kepustakaan, 1st ed. (Malang: Literasi Nusantara, 2020).

${ }^{9}$ Ibid.

${ }^{10}$ Andreas B. Subagyo, Pengantar Riset Kuantitatif Dan Kualitatif, 1st Ed. (Bandung: Yayasan Kalam Hidup, 2004).

${ }^{11}$ Amir, Metode Penelitian Kepustakaan, 21.
} 
dengan menganalisa buku untuk menemukan pemikiran dan karya asli dari tokoh yang sedang diteliti. ${ }^{12}$

\section{HASIL DAN PEMBAHASAN}

\section{Perjalanan Pelayanan Pdt. H.L. Senduk}

1. Kiprah H.L. Senduk bagi kekristenan di Indonesia sangatlah banyak, seperti berikut ini: sejak tahun 1945 sebagai sekretaris pimpinan pusat sinode GpdI, tahun 19451946 sebagai gembala GpdI di Tasikmalaya - Jawa Barat, tahun 1950 sebagai gembala GpdI di Petamburan - Jakarta, tahun 1952 ia keluar dari GpdI dan mendirikan GBIS di Surabaya, serta menjadi Ketua Badan Penghubung sejak tahun 1955, tahun 1952 mendirikan yayasan Behtel -untuk mendukung kegiatan gereja dalam penginjilan, pendidikan teologi, pendidikan umum, kesehatan, dan sosial lainnya-, tahun 1956 mendirikan Sekolah Penginjil Bethel (SPB), tahun 1968 mendirikan Sekolah Pendidikan Guru Agama (Kristen) Protestan yang sekarang bernama Sekolah Menengah Theologia Bethel (SMTB), tahun 1968 mendirikan Akademi Teologi Bethel (ATB) yang lebih dikenal dengan Seminari Bethel, tahun 19661980 anggota Badan Pengurus Lembaga Alkitab Indonesia (LAI), tahun 1967 membangun kerja sama dengan Church of God (COG), tahun 1970 mendirikan sinode GBI, tahun 1972 menjadi ketua sinode GBI kedua hingga tahun 1994 saat sidang sindoe X, ia menjadi ketua Badan Pembina Rohani GBI. ${ }^{13}$

Kiprah H.L. Senduk yang sangat besar atas kekristenan di Indonesia, maka penulisan tentang Tokoh Pdt. H.L. Senduk ini sangat penting dan menarik serta berimplikasi strategis bagi kekristenan di Indonesia khususnya, sebagaimana juga dinyatakan oleh Rudy N. Assa bahwa gereja membutuhkan figur yang dapat dijadikan rujukan yang kehidupan dan pelayanannya menggambarkan kehidupan kekristenan tentang pemimpin, pendeta dalam pengabdian kepada Allah yang memuaskan. ${ }^{14}$ Pendeta Markus D. Wakkary selaku ketua umum Persekutuan Gereja-gereja Pentakosta Indonesia pada tahun 2001 dalam sambutannya pada buku tentang H.L. Senduk mengatakan bahwa H.L. Senduk merupakan sesepuh dalam pergerakan pentakosta di Indonesia dan benua Asia, serta bapa rohani GBI

\footnotetext{
${ }^{12}$ Ibid, 24.

13 "Ho Lukas Senduk."

${ }^{14}$ Rudy N. Assa, Tokoh-Tokoh Kristen Yang Mewarnai Dunia, 6th ed. (Yogyakarta: Andi Offset, 2009).
}

Copyright@2021; Ritornera - Jurnal Teologi Pentakosta Indonesia, ISSN 2797-7676 (online), 2797717x (print) | 104 
dan sebagai pendiri Persekutuan Pentakosta Indonesia (PPI) yang merupakan awal mula dari PGPI, maka secara implisit dapat dikatakan H.L. Senduk adalah bapa rohani PGPI. ${ }^{15}$

Kehidupan Pdt. H.L. Senduk merupakan kehidupan dengan penuh rela membayar harga dengan kerja keras, pergaulan yang benar, dengan memilih gaya hidup dalam kesucian. Kehidupan banyak orang Kristen menampilkan gaya hidup yang tidak berbeda dari orang-orang pada umumnya. Pembaharuan pikiran setiap hari merupakan hal penting untuk dialami oleh orang pecaya, agar tidak serupa dengan dunia ini. ${ }^{16}$ Pdt. H.L. Senduk merupakan sosok pribadi yang terus mencari wajah Tuhan dan bersekutu dengan komunitas yang mencintai Tuhan sehingga anugerah Tuhan terus mengalir dan memimpin dengan nyata dan luar biasa, hal ini senada dengan konsep pentingnya mencari wajah Tuhan selama seseorang hidup dan bagaimana pengaruh kekuatan tekad dan keterbukaan hati seseorang untuk tidak memikirkan apapun selain Tuhan merupakan hal yang penting agar Tuhan dapat merubah dan memakai hidupnya ${ }^{17}$.

\section{Perjalanan H.L. Senduk dalam Kegerakan Pentakosta}

Perjalanan H.L. Senduk tidak bisa dilepaskan dari sejarah GpdI. GpdI dulu dikenal sebagai Gereja Pentakosta. Rev. D. Van Kleveren dan C. Groesbeek merupakan missionaris dari Bethel Pentecostal Temple Inc., Seattle, Washington, USA yang diutus oleh Pdt. W.H. Offiler pada tahun 1921. Mereka merupakan orang Amerika keturunan Belanda. Penglihatan tentang pulau Bali didapatkan oleh mereka sewaktu berdoa pengutusan. Oleh karena itu dalam ketaatan, pelayanan misionaris mereka dilakukan di pulai Bali. Seiring berjalannya waktu, C. Groesbeek pindah ke kota Surabaya dan Van Klaveren ke kota Lawang pada tahun 1922. Selanjutnya Groosbeek berjumpa dengan F.G. Van Gessel yang berdenominasi Kristen Injili dan merupakan karyawan dari Bataafsche Petroleum Maatschappij saat ia pergi ke kota Cepu.

Baptisan Roh kudus terjadi atas nyonya Van Gessel pada Januari 1923, serta merupakan seorangh wanita pertama di Indonesia yang mengalaminya. Setelah beberapa waktu kemudian, baptisan Roh Kudus terjadi atas F.G. Van Gessel. Baptisan Air yang pertama dari Jemaat Pantekosta Cepu dilakukan pada tanggal 30 Maret 1923. Kemudian Groesbeek kembali ke kota Surabaya, dan kepemimpinan Jemaat di Cepu diteruskan oleh

\footnotetext{
${ }^{15}$ M. Ferry H. Kakiay, H.L. Senduk Bapa Rohani GBI Sejarah, Kepemimpinan, Teologi, Visi Dan Misi (Jakarta: Gereja Bethel Indonesia Jemaat Kapernaum, 2001), xv-xvi.

${ }^{16}$ Erastus Sabdono, Mencapai Kesucian, 3rd Ed. (Jakarta: Rehobot Literature, 2016).

${ }^{17}$ Erastus Sabdono, All Out for Christ, 1st Ed. (Yogyakarta: Andi Offset, 2009).
} 
Van Gessel yang juga telah menjadi Evangelist. gerakan Pantekosta diakui sebagai De Pinkister Gemeente in Nederlands Indie oleh pemerintah Hindia Belanda pada 4 Juni 1924. Setelah 13 tahun, yakni pada tanggal 15 juni 1937 status Kergenotschap diberikan kepada Gereja Pentakosta dan akhirnya menjadi De Pinkister Kerk in Nederlands Indie. Kota Batavia (Jakarta) merupakan kota selanjutnya yang didatangi oleh Groesbeek dan Van Klaveren yang dilakukan pada bulan April 1926. Sesuai panggilan yang Tuhan berikan kepada F.G. Van Gessel, maka akhirnya ia menggembalakan Jemaat Tuhan yang ada di Surabaya, sehingga jabatan sebagai Pegawai Tinggi di BPM Cepu ditinggalkan oleh Van Gessel. Gereja Pentakostadi Surabaya mengalami perkembangan yang pesat di bawah kepemimpinan Van Gessel. Sebuah Gedung Gereja dengan kapasitas 1.000 tempat duduk (gereja yang terbesar di Surabaya) pada tahun 1932.

Sekolah Alkitab Studi Tabernakel didirikan tahun 1935 oleh F.G. Van Gessel. W.W. Patterson merupakan salah seorang misionaris yang diutus oleh Bethel Pentacostal Temple di Seattle, Washington pada tahun 1935. Ia melakukan perjalanan misinya dengan mendirikan Sekolah Akitab di Surabaya yang bernama Netherlands Indies Bible Institute (NIBI). H.L. Senduk mengalami perjumpaan dengan Kristus, sehingga mengalami pertobatan, kemudian dibaptis air pada 19 April 1935 dan mengalami baptisan Roh Kudus pada 26 April 1935, serta H.L. Senduk juga bergabung dengan Gereja Pentakosta. ${ }^{18}$ Sekitar tahun 1935 (saat umur 19 tahun) H.L. Senduk pergi ke Surabaya untuk belajar teologi dari F.G. Van Gessel, serta tinggal di rumahnya juga. Periode tahun 1942 terjadi permasalahan di dalam GPdI, yakni seruan mempribumikan semua kolonial, sehingga F.G Van Gessel tidak lagi menjadi ketuanya, melainkan H.N. Runkat yang terpilih. Walaupun F.G. Van Gessel sudah tidak menjadi ketua GPdI, perjumpaan dengan Tuhan membuat perubahan atas diri H.L. Senduk, serta membuat dirinya menonjol dalam kepemimpinan rohani sejak masa mudanya dalam lingkungan pentakosta. ${ }^{19}$

Tahun 1950-an adalah tahun terjadinya degradasi persatuan, karena diskriminasi rasis untuk keturunan tionghoa yang terjadi secara sosial politik anti Cina, sehingga membuat kepemimpinan nasional gereja pentakosta mengalami krisis dan membuat celah bagi banyak orang untuk membuat gereja hampir tidak bisa bersatu sebagai tubuh Kristus. ${ }^{20}$ H.L. Senduk dan rekan-rekannya menghadapi kondisi ini dengan mendeklarasikan reformasi iman yang dijalankan dengan keyakinan bahwa hanya Yesus Kristus yang dapat membuat

\footnotetext{
${ }^{18}$ Kakiay, H.L. Senduk Bapa Rohani GBI Sejarah, Kepemimpinan, Teologi, Visi Dan Misi, 15.

${ }^{19}$ Ibid, 14.

${ }^{20}$ Ibid.
} 
perubahan dan pembaharuan di dalam kehidupan manusia. ${ }^{21}$ Sejak masa mudanya H.L. Senduk memegang konsistensi untuk menjalankan kebenaran yang pastinya menjadi dasar sikapnya untuk menentang ketidakbenaran yang terjadi di gereja, seperti diskriminasi rasial ini. Permasalahan demi permasalahan terus terjadi dan membuat 22 orang pendeta memilih untuk berpisah dari sinode Gereja Pantekosta pada tahun 1952.

F.G. Van Gessel bersama H.L. Senduk dan para pendeta lainnya yang keluar dari GPdI berkumpul dan membentuk sinode baru dan memberikan nama Gereja Bethel Injil Sepenuh (GBIS). ${ }^{22}$ Pertemuan tersebut memutuskan untuk mengangkat Van Gessel dipilih menjadi ketua dan H.L. Senduk terpilih sebagai Ketua Badan Penghubung dan hal ini dilakukan bersamaan dengan penggembalaan gereja di Jakarta dan Van Gessel kembali kepada jemaatnya di Surabaya. ${ }^{23}$ Kepemimpinan mereka membuat pertumbuhan dan perkembangan terus terjadi di GBIS sekalipun berbagai rintangan tetap dihadapi. GBIS mengalami perkembangan yang pesat saat dipimpin oleh H.L. Senduk yang terlihat sejak tanggal 1 April 1954 dengan dimulainya Kursus Sekolah Penginjil, lalu pada tanggal 7 April 1956 dimulainya Sekolah Penginjil Bethel. ${ }^{24}$ Seiring berjalannya waktu, Tuhan memperbesar pelayanan H.L. Senduk dengan membuat Sekolah Pendidikan Guru Agama Kristen di tahun 1968, yang akhirnya menjadi Seminari Bethel. ${ }^{25}$ Tuhan menuntun H.L. Senduk untuk membangun kerjasama antara GBIS dan Church Of God yang berada di Clevelent, Tennese, Amerika yang perjanjiannya ditandatangani dua kali, yakni pada 9 Februari 1967 yang disebut Amalgamation dilakukan di Jakarta dan pada 9 Maret 1967 dilakukan di Clevelent, namun Pdt. J. Setiawan yang berasal dari Solo dan kelompoknya tidak menyetujui kerja sama tersebut. ${ }^{26}$

Perselisihan ini timbul, karena kelompok H.L. Senduk diminta oleh kelompok J. Setiawan untuk menghentikan pembangunan seminari, dan dipergunakan untuk dibagikan saja. ${ }^{27} \mathrm{Hal}$ ini terjadi, karena diketahuinya informasi bahwa adanya bantuan berupa dana dari gereja luar negeri, sehingga dorongan untuk dana tersebut dialihkan kepada gereja-gereja

${ }^{21}$ Ibid.

22 David Soemantri, "Perjalanan Panjang 50 Tahun Gereja Bethel Injil Sepenuh Mengemban Amanat Agung (Sejarah Kelahiran \& Perkembangannya)," GBIS-Online, last modified 2018, https://www.gbis-online.com/copy-of-sejarah-gbis.

${ }^{23}$ Matheus Kevin, "Laporan Praktik Kerja Lapangan Pada Badan Pekerja Daerah Gereja Bethel Indonesia DKI Jakarta” (Universitas Negeri Jakarta, 2018), http://repository.fe.unj.ac.id/6835/, 11.

${ }^{24}$ Ibid.

25 "Bio-Kristi Situs Biografi Kristiani Ho Lukas Senduk," https://biokristi.sabda.org/ho_lukas_senduk.

${ }^{26}$ Kevin, "Laporan Praktik Kerja Lapangan Pada Badan Pekerja Daerah Gereja Bethel Indonesia DKI Jakarta", 12

27 Ibid. 
yang membutuhkan dana dan tidak melihat kepada visi dari H.L. Senduk, sehingga terjadinya krisis internal di GBIS. ${ }^{28}$ Konsistensi H.L. Senduk untuk tetap mengalokasikan dana tersebut dan menolak permintaan untuk mengubah fungsi dana tersebut menyebabkan terjadinya rapat penasehat di Prapat - Sumatera Utara pada 17-20 Juli 1969 yang dipelopori oleh kelompok J. Setiawan, dan menghasilkan keputusan untuk memecat seluruh kelompok dari H.L. Senduk di tubuh GBIS. ${ }^{29}$ Permasalahan ini membuat kelompok H.L. Senduk memberikan pertanyaan secara resmi kepada pemerintahan saat itu dan mendapatkan jawaban dari Menteri Agama berdasarkan surat tanggal 3 Oktober 1970 yang berisi bahwa kepemimpinan yang diakui oleh pemerintah adalah dari GBIS Pusat Solo dan pemerintah memberikan kesempatan untuk mendirikan organisasi gereja baru.

Kelompok H.L. Senduk menyikapi jawaban surat dari menteri agama dengan membuat acara di Sukabumi pada 5-8 Oktober 1970, namun dibatalkan karena telah diketahui oleh kelompok Solo. Walaupun acara tersebut batal, Yayasan Gereja Bethel Indonesia di Bandung didirikan oleh Pdt. T. Jonathan dan Pdm. J.F.R. Montolalu berdasarkan akte Yayasan GBI no 82/1970, sehingga GBIS jemaat Paturiani Bandung memutuskan keluar dari sinode GBIS dan bergabung dengan Yayasan GBI, serta mendaftarkan dan melaporkan diri kepada Bimas Kristen Kementerian Agama Provinsi Jawa Barat sebagai GBI yang pertama pada 29 September $1970 .{ }^{30}$ Pada 6-7 Oktober 1970 kelompok H.L. Senduk dengan menggunakan nama Yayasan Gereja Bethel Indonesia mengadakan pertemuan di Wisma Oikumene PGI yang berada di jalan Bayangkara Sukabumi dengan keputusan pada 6 Oktober 1970 mendirikan sinode Gereja Bethel Indonesia. ${ }^{31}$ Keputusan ini diperkuat dengan penerbitan Surat Keterangan Departemen Agama Dirjen Bimas Kristen/Protestan no Dd/P/VII/57/748/70 pada tgl. 16 Oktober 1970 perihal berdirinya sinode GBI. H.L. Senduk sendiri baru menjadi ketua sinode berdasarkan sidang Sinode ke II tahun 1972 sampai sidang Sinode IX tahun 1994. ${ }^{32}$

\section{H.L. Senduk dan Kegerakan Pentakosta}

Perjumpaan H.L. Senduk dengan Roh Kudus terjadi pada 26 April 1935 yakni saat mengalami baptisan Roh Kudus di gereja Pentakosta dan perjumpaan tersebut terus berlanjut

\footnotetext{
${ }^{28}$ Kakiay, H.L. Senduk Bapa Rohani GBI Sejarah, Kepemimpinan, Teologi, Visi Dan Misi, 24.

${ }^{29}$ Kevin, "Laporan Praktik Kerja Lapangan Pada Badan Pekerja Daerah Gereja Bethel Indonesia DKI Jakarta”, 13

${ }^{30}$ Ibid.

31 "Sejarah Singkat Lahirnya Gereja Bethel Indonesia," BPD GBI Kepulauan Riau, last modified 2020, https://www.youtube.com/watch?v=kwdY2xpAEOE\&t=1s.

${ }^{32}$ Kevin, "Laporan Praktik Kerja Lapangan Pada Badan Pekerja Daerah Gereja Bethel Indonesia DKI Jakarta”, 14
}

Copyright(C2021; Ritornera - Jurnal Teologi Pentakosta Indonesia, ISSN 2797-7676 (online), 2797 $717 x$ (print) $\mid 108$ 
hingga Roh Kudus menuntun dirinya untuk belajer Teologi saat usia 19 tahun bersama Van Gessel dan mulai merintis jemaat pada usia 22 tahun di Banda Neira, Maluku. ${ }^{33}$ H.L. Senduk selalu mengikuti didikan dan arahan gurunya, Pdt. Frans Gerald van Gessel yang berasal dari Gereja Pentakosta (GpdI). Kesetiaan dan ketaatan tersebut menuntun perjalanan H.L. Senduk dalam kegerakan pentakosta yang ditandai dengan lahirnya Gereja Bethel Injil Sepenuh (GBIS) dari kelompok Pentaksota di Indonesia pada 21 Januari 1952 dengan H.L. Senduk menjadi pimpinan organisasi pertama dan Van Gessel menjadi pimpinan rohani. ${ }^{34}$ Hal tersebut terjadi bersamaan dengan kondisi Gereja Pentakosta yang sedang mengalami diskriminasi rasial yang membuat degradasi persatuan yang harusnya menjadi bentuk iman akan tubuh kristus. ${ }^{35}$ Perselisihan yang terjadi di GBIS yang membuat H.L. Senduk mengambil keputusan etis dengan keluar menyebabkan dirinya dicap sebagai pembangkang hanya karena tetap memegang prinsipnya terhadap keputusan yang ia ambil. ${ }^{36}$ Sikap ini menanamkan prinsip bahwa setiap sangat penting bagi gereja mewaspadai adanya kekakuan rohani ataupun institusi yang dapat menghambat pergerakan Roh Kudus atas kehidupan dan pelayanan. ${ }^{37}$ Perpisahan dengan (GBIS) pastinya membuat terjadinya kelahiran Gereja Bethel Indonesia (GBI) yang dimulai dari Yayasan Bethel dan diresmikan secara hukum pada tahun 1970 yang dipimpin oleh H.L. Senduk selama 8 periode kepemipinan menjadi gereja yang terus berkembang dengan berbagai bidang pelayanan yang menunjukkan dinamisnya organisasi gereja yang berusaha menjawab kebutuhan masyarakat.

Pada tahun 1958 H.L. Senduk menjadi ordained minister dari Church of God (COG). Bahkan menjadi anggota Badan Pekerja Lengkap COG periode 1989-1992. ${ }^{38}$ Pada tahun 1989 H.L. Senduk berkotbah pada Dewan Pentakosta Indonesia tentang pentingnya gereja bekerjasama antarorganisasi untuk memenuhi visi Tubuh Kristus. ${ }^{39}$ Hal tersebut pastinya membuat gereja berdenominasi pentakosta untuk berjalan dalam kesatuan Tubuh Kristus. Arahan demi arahan beliau lakukan selama memimpin GBI yang pastinya membuat GBI mengalami pertumbuhan yang lebih cepat gari gerakan pentakosta dimanapun. ${ }^{40}$ Dalam kepemimpinan beliau atas GBI ataupun dalam pelayanannya terhadap berbagai gereja, H.L. Senduk menunjukkan wawasan dan komitmennya dalam kepemimpinan yang mengayomi

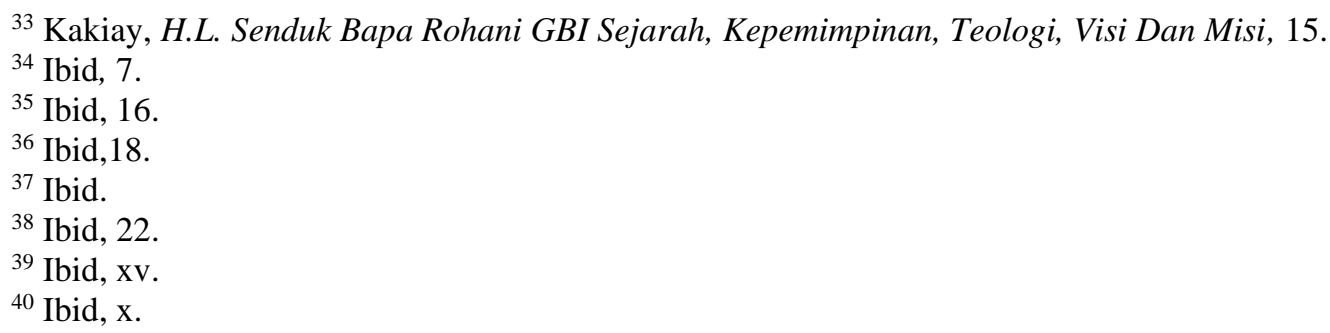


sebagai bapa. ${ }^{41}$ Jadi kehidupan H.L. Senduk dalam pelayanan memberikan pengaruh yang sangat besar kepada kegerakan pentakosta di Indonesia, mengingat ia berasal dari GPdI yang merupakan gereja pentakosta tertua di Indonesia, serta melahirkan 2 sinode besar di Indonesia yang pastinya mewarnai kegerakan pentakosta di Indonesia, yakni GBIS dan GBI.

\section{Warisan Rohani}

Sebagai seorang bapa, pasti akan meninggalkan warisan kepada anak yang ia tinggalkan ketika ia berpulang ke rumah Bapa di surga. Hal ini pastinya dilakukan H.L. Senduk bagi setiap orang percaya, khususnya denominasi pentakosta di Indonesia. Warisan rohani H.L. Senduk yang ditinggalkan bagi orang percaya dapat dikelompokkan sebagai berikut: teologi H.L. Senduk, kepemimpinan, dan pelayanan.

Adapun teologi H.L. Senduk yang ditinggalkan bagi gereja-gereja pentakosta di Indonesia pastinya menekankan iman akan kuasa Roh Kudus dan juga logika, serta mengandung unsur pietisme yang tidak kaku, teologi logis, dan juga teologi mistik. Teologi H.L. Senduk memiliki peinsip pentingnya teologi dalam sebuah usaha untuk mengenali Tuhan secara benar dan sistematis dengan mengedepankan setiap manusia harus membuka pemikirannya terhadap segala pekerjaan Roh Kudus untuk mengalami perubahan pemikiran manusia, sehingga memiliki pemahaman yang baru dan orisinil yang alkitabiah, serta peranan akal budi sebagai pemberian Tuhan secara cuma-cuma yang penting untuk dihargai dan dipergunakan untuk memuliakan Tuhan. ${ }^{42}$ Teologi H.L. Senduk juga menekankan pentingnya manusia membuka diri dan pikiran terhadap pekerjaan Roh Kudus dalam menyatakan kuasa Allah melalui mujizat yang dapat terjadi di dalam kehidupan manusia. ${ }^{43}$

Konsep teologi H.L. Senduk ini dirangkum menjadi 14 butir pernyataan iman rasuli dari GBI yang menjadi dasar dari sinode GBI hingga saat ini. ${ }^{44} 14$ butir pernyataan iman rasuli dari GBI dapat dikatakan sebagai dasar pemahaman tentang konsep gereja, dasar gereja, azaz gereja dalam bermasyarakat, visi dan misi gereja yang pastinya sesuai dengan tata dasar GBI. ${ }^{45}$ Konsep tersebut dapat dirangkum menjadi 4 pemikiran pokok, seperti:pertama melalui kematian, kebangkitan, dan kenaikan Tuhan Yesus ke surga, maka Ia merupakan juruselamat dan penebus manusia. Kedua melalui pengorbanan-Nya, maka Tuhan Yesus merupakan Penyembuh atas segala sakit penyakit bagi orang yang percaya

${ }^{41}$ Ibid, xvi.

42 Ibid, 32.

${ }^{43}$ Ibid.

${ }^{44}$ Ibid, 28.

${ }^{45}$ M. Ferry H. Kakiay, Rasul-Rasul GBI Pola Pelayanan Kerasulan Kunci Pertumbuhan GBI (Jakarta: Gereja Bethel Indonesia Jemaat Kapernaum, 2002), 86.

Copyright@2021; Ritornera - Jurnal Teologi Pentakosta Indonesia, ISSN 2797-7676 (online), 2797$717 x$ (print) $\mid 110$ 
kepada-Nya. Ketiga hanya Tuhan Yesus yang membaptis orang yang percaya kepada-Nya dengan Roh Kudus, serta memberikan karunia dan berkat kepada setiap orang percaya. Keempat bahwa gereja merupakan mempelai Kristus dan Kristus adalah Raja atas segala raja.

H.L. Senduk juga menekankan konsep doa Bapa Kami yang harus dijadikan dasar hubungan antara manusia dengan Allah. Tujuh pokok pemikiran H.L. Senduk dalam doa Bapa Kami adalah (1) Bagi setiap orang yang percaya dan menerima Tuhan Yesus sebagai Tuhan dan juruselamat pribadinya, maka memiliki hak untuk menjadi anak Allah, sehingga dapat memanggil Allah sebagai Bapa dan memiliki hubungan keluarga (Yoh. 1:12, 2 Kor.5:17, Rm.8:15-16). (2) Nama Tuhan adalah nama yang kudus yang pastinya menyelamatkan manusia dan menghancurkan pekerjaan iblis, sehingga setiap orang percaya yang menjadi anak Allah harus menjaga kehidupannya dalam kekudusan, sehingga dapat berdoa dengan benar juga (Ibr.12:14, 1 Ptr.1:15-16). (3) Kehadiran Tuhan Yesus adalah untuk menyatakan Kerajaan Allah. Saat ini Kerajaan Allah berada di dalam gereja Tuhan, sehingga kita harus menyatakan kerajaan Allah dan mempersiapkan diri untuk kedatangan Tuhan yang kedua kali (Mat.24:27, Why.1:7, Mrk.13:32-37). (4) Kehendak Allah merupakan sebuah ketetapan yang mutlak, sehingga kita sebagai anak harus dapat berdoa dan berjalan dalam tunduk dan taat terhadap kehendak Allah (Mat.26:39,42,44; Flp.2:13, 1 Yoh.3:22). (5) Kehidupan seorang anak Tuhan bukanlah hidup untuk makan, melainkan makan untuk hidup. Kehidupan anak Allah seharusnya mengutamakan Kerajaan Allah dan mengalami pemelihataan Tuhan dan berkat-Nya (Mat.5:45, 6:32-33). (6) Kehidupan manusia memiliki dosa dan kesalahan, oleh karena penebusan Tuhan Yesus, maka setiap dosa anak Allah diampuni dan dikuduskan, namun memerluan hati yang tidak memiliki kebencian di dalam kehidupannya (1Yoh.1:7, 2:1-2, Mat.18:21-25). (7) Pekerjaan inlis adalah untukk menjatuhkan anak Tuhan ke dalam dosa dengan memengaruhi hati dan pikirannya. Sangat penting untuk anak Allah bergantung kepada Allah, sehingga mengalami anugerah Tuhan yang menguatkan anak Allah (Ef.6:10-18, 1 Ptr.5:8-10, Why.12:9-11).

Kepemimpinan H.L. Senduk juga memberikan warisan rohani bagi setiap insan pentakosta, khususnya di Indonesia terlebih lagi melihat perkembangan GBI yang sangat signifikan. Kepemimpinan H.L. Senduk baik pada keluarganya ataupun dalam sinode GBI dan juga dalam pelayanannya dilakukan dengan baik. Bagi H.L. Senduk memimpin keluarga terlebih dahulu dengan baik sesuai Firman Tuhan merupakan hal terpenting sebelum menjadi pelayan Tuhan. Kepemimpinannya dalam keluarga pastinya dimulai dari mendapatkan seorang istri yang takut akan Tuhan dan memiliki karakter sesuai Firman Tuhan. 
Kepemimpinan H.L. Senduk merupakan kepemimpinan yang penuh dengan kedinamisan, kreatif, inovatif, integritas diri, memberikan inspirasi, memberikan kekuatan, tidak kompromi terhadap dosa, memberikan pengajaran dan arahan kepada orang yang dipimpinnya, visioner dan selalu memiliki ide-ide yang baru. ${ }^{46}$

Dalam kepemimpinan H.L. Senduk sangat mengutamakan kuasa Roh Kudus, namun ia menggunakan karunia-karunia rohaninya untuk membangun tubuh Kristus dan tidak menggunakannya untuk penyalahgunaan wewenang rohani dan manipulasi Firman. ${ }^{47}$ Kepemimpinan H.L. Senduk di gereja menunjukkan bahwa gereja harus memiliki kedinamisan yang teraplikasikan dalam penginjilan, pengajaran, dan penggembalaan. H.L. Senduk memberikan warisan rohani yang sangat penting bagi gereja, yakni seorang pemimpin memiliki kriteria penginjilan yang dilakukannya. Kepemimpinan H.L. Senduk membuat dasar terbentuknya budaya organisasi di sinode GBI yang terlihat dari penanaman nilai-nilai, norma-norma, dan visi. Kepemimpinan H.L. Senduk mendapatkan pujian dari Yakob Tomatala sebagai pemimpin yang bijak daipakai oleh Allah untuk memberkati banyak orang, sehingga nama Allah dipermuliakan. ${ }^{48}$

M.D. Wakkary menerangkan bahwa H.L. Senduk merupakan seorang pelayan Tuhan dan pemimpin visioner yang hebat dengan disertai hikmat dan kearifan dalam memimpin, serta memiliki kinerja di GBI dan wadah lainnya, serta pelayanan misi yang selalu memuliakan Tuhan Yesus. Chris Marantika mengatakan bahwa H.L. Senduk sebagai sesepuh denominasi Injili dalam kehidupannya memancarkan keindahan Ilahi dengan kehidupan yang saleh, sederhana, terbuka terhadap karya Roh Kudus dalam pelayanannya, dan aktif dalam bekerja. Selain itu Sularso Sopater menerangkan bahwa H.L. Senduk merupakan pemimpin dan organisatoris yang baik dengan menekankan pentingnya kesatuan tubuh Kristus (oikumenis). ${ }^{49}$

Pelayanan yang dilakukan oleh H.L. Senduk sangatlah berdampak bagi kalangan pentakosta, khususnya dapat terlihat pada pelayanan yang dilakukan oleh sinode GBI. Pelayanan yang paling utama terlihat adalah penginjilan. Metode penginjilan H.L. Senduk menunjukkan kesederhanaan, relevan dengan adanya kesaksian hidup, efektif yang berpusat pada polarisasi kehidupan. Oleh karena itu H.L. Senduk menunekankan bahwa gereja harus sadar akan realitas sosial, baik keluarga dan lingkungan sekitar yang memerlukan Injil.

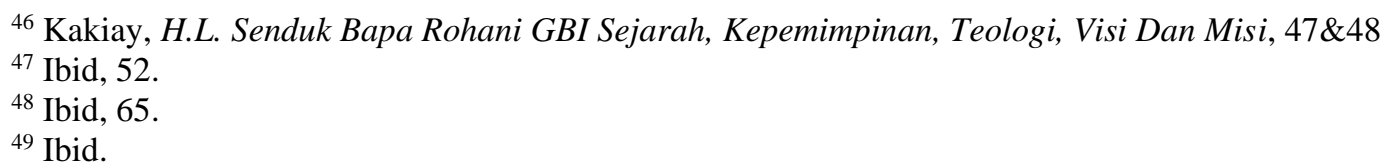


Penginjilan yang dilakukan berfokus pada keeksklusifan Injil bahwa keselamatan manusia hanya bergantung dari anugerah Tuhan yang diberikan. Konsep penginjilan pun dikategorikan menjadi 3 kelompok oleh H.L. Senduk, yakni: (1) Kelompok manusia yang sembarang, yakni tidak memiliki kesadaran dan pengetahuan akan keselamatan jiwa, (2) Kelompok yang tahu bahwa mereka membutuhkan keselamatan namun belum lahir baru (bertobat dan mengikuti Tuhan), (3) Kelompok yang sadar akan keselamatan jiwanya, serta memiliki kerinduan, namun tidak tahu jalannya. ${ }^{50}$

Dalam menjawab realitas sosial yang relevan, kepemimpinan H.L. Senduk di sinode GBI pastinya mencanangkan 4 bidang pelayanan, yakni (1) Bidang pelayanan pendidikan umum (2) Bidang pelayanan kesehatan masyarakat (3) Bidang pelayanan sosial untuk masyarakat yang tidak mampu (4) Bidang pelayanan pada media. ${ }^{51}$ Sesuai konsep teologis dan prinsip kepemimpinan H.L. Senduk mengenai pentingnya kesatuan tubuh Kristus (oikumene), maka H.L. Senduk membawa GBI bergabung dengan 3 aras nasional, yakni PGI, PGPI, PGLII/ PII yang berpartisipasi secara aktif sebagai anggota organisasi aras tersebut. ${ }^{52}$ Pelayanan H.L. Senduk membuat sinode GBI terus mengalami perkembangan dan pertumbuhan baik secara kuantitas ataupun kualitas dari tahun 1970 yang berjumlah 129 jemaat hingga pada tahun 2002 memiliki sekitar 3500 jemaat lokal dan 5000 pejabat gereja. ${ }^{53}$ Pada tahun 2021 ini sinode GBI merupakan sinode terbesar ketiga dengan jumlah jemaat 2.500.000 hingga 3.000.000 jemaat. ${ }^{54}$

\section{KESIMPULAN}

H.L. Senduk merupakan seorang tokoh penting bagi denominasi pentakosta di Indonesia yang memberikan sumbangsih sangat besar, khususnya melalui sinode GBI. Kehidupan H.L. Senduk dari gereja Pentakosta memberikan warna bagi kegerakan pentakosta di Indonesia, karena melahirkan GBIS dan GBI. H.L. Senduk menaruh dasar yang penting bagi gereja pentakosta, yakni pentingnya gereja untuk bersifat dinamis dan terbuka kepada karya Roh Kudus, serta penekanan teologi yang berimbang baik secara logis, teologis, sistematis, alkitabiah, serta terbuka terhadap karya Roh Kudus untuk terjadinya mujizat. Pemikiran teologis H.L. Senduk dicantumkan dalam 14 butir pernyataan iman rasuli

${ }^{50}$ Ibid, 46.

${ }^{51}$ Kakiay, Rasul-Rasul GBI Pola Pelayanan Kerasulan Kunci Pertumbuhan GBI, 90.

52 Ibid, 87.

${ }^{53}$ Ibid, 92.

54 “20 Gereja Terbesar Di Indonesia (Berdasarkan Jumlah Jemaat / Sinode)," Katekisasi Online, last modified 2021, https://youtu.be/fo60M-fQPis. 
sinode GBI. Sebagai seorang pemimpin rohani, kepemimpinan H.L. Senduk pastinya sangat berpengaruh bagi kalangan pentakosta, karena memiliki visi yang hebat, karakter yang baik, dan teladan yang luar biasa bagi setiap generasi. H.L. Senduk tidak hanya memimpin, namun memastikan pelayanan merupakan salah satu karakternya. Pelayanan misi / penginjilan adalah hal utama yang ditekankan oleh H.L. Senduk yang dilakukan dengan melihat realitas sosial dengan menjawab secara relevan dan seefektif mungkin pada setiap aspek yang ada.

\section{REFERENSI}

Amir, Hamzah. Metode Penelitian Kepustakaan. 1st ed. Malang: Literasi Nusantara, 2020.

Assa, Rudy N. Tokoh-Tokoh Kristen Yang Mewarnai Dunia. 6th ed. Yogyakarta: Andi Offset, 2009.

Furchan, Arief, and Agus Maimun. Studi Tokoh Metode Penelitian Mengenai Tokoh. 1st ed. Yogyakarta: Pustaka Pelajar, 2005.

Ghozali, H. Imam. Metodologi Penelitian Kualitatif Analisis Data Kualitatif Dengan NVIVO 12. 1st ed. Semarang: Yoga Pratama, 2020.

Harahap, Syahrin. Metodologi Studi Tokoh Dan Penulisan Biografi. 2nd ed. Jakarta: Prenada Media, 2014.

Kakiay, M. Ferry H. H.L. Senduk Bapa Rohani GBI Sejarah, Kepemimpinan, Teologi, Visi Dan Misi. Jakarta: Gereja Bethel Indonesia Jemaat Kapernaum, 2001.

_. Rasul-Rasul GBI Pola Pelayanan Kerasulan Kunci Pertumbuhan GBI. Jakarta: Gereja Bethel Indonesia Jemaat Kapernaum, 2002.

Kevin, Matheus. "Laporan Praktik Kerja Lapangan Pada Badan Pekerja Daerah Gereja Bethel Indonesia DKI Jakarta." Universitas Negeri Jakarta, 2018. http://repository.fe.unj.ac.id/6835/.

Sabdono, Erastus. All Out for Christ. 1st Ed. Yogyakarta: Andi Offset, 2009.

-. Mencapai Kesucian. 3rd Ed. Jakarta: Rehobot Literature, 2016.

Soemantri, David. "Perjalanan Panjang 50 Tahun Gereja Bethel Injil Sepenuh Mengemban Amanat Agung (Sejarah Kelahiran \& Perkembangannya)." GBIS-Online. Last modified 2018. https://www.gbis-online.com/copy-of-sejarah-gbis.

Subagyo, Andreas B. Pengantar Riset Kuantitatif Dan Kualitatif. 1st Ed. Bandung: Yayasan Kalam Hidup, 2004.

Sugiyono. Metode Penelitian Manajemen. 3rd Ed. Bandung: Alfabeta, 2014.

"20 Gereja Terbesar Di Indonesia (Berdasarkan Jumlah Jemaat / Sinode)." Katekisasi Online. Last modified 2021. https://youtu.be/fo60M-fQPis.

"Bio-Kristi Situs Biografi Kristiani Ho Lukas Senduk." https://biokristi.sabda.org/ho_lukas_senduk.

"Ho Lukas Senduk." https://dbr.gbi-bogor.org/wiki/Ho_Lukas_Senduk.

"Sejarah Singkat Lahirnya Gereja Bethel Indonesia." BPD GBI Kepulauan Riau. Last modified 2020. https://www.youtube.com/watch?v=kwdY2xpAEOE\&t=1s. 